\title{
Exploring the Relationship Between Locus of Control and Financial Behavior of Accounting Student from The Social Construction Theory Approach
}

\author{
Wirawan ED Radianto ${ }^{*}$ \\ Baswara Yua Kristama \\ Ika Raharja Salim² \\ ${ }^{1}$ Department of Accounting, Universitas Ciputra Surabaya, \\ CitraLand CBD Boulevard, Made, Sambikerep, \\ Surabaya City, East Java 67219, Indonesia \\ ${ }^{2}$ Centre of Research and Community Development, \\ Universitas Ciptura Surabaya, \\ CitraLand CBD Boulevard, Made, Sambikerep, \\ Surabaya City, East Java 67219, Indonesia \\ *Corresponding Author
}

DOI: https://doi.org/10.36941/ajis-2021-0043

\begin{abstract}
This research examines the effect of locus control on financial literacy, including financial attitude, financial behavior, and financial self-efficacy. This study used a survey method by sending a questionnaire to the respondent through an enumerator. This study uses a sample, namely students of the accounting study program in Surabaya, Indonesia. A total of 159 questionnaires were processed from distributing 250 questionnaires randomly. This study uses the Partial Least Square data analysis. The result shows that locus of control affects financial attitude, financial behavior, and financial self-efficacy. Financial behavior increases when the respondents show excellent financial knowledge behavior and believe that they can manage for their finances. This investigation confirms that locus of control affects financial behavior. Meaning the role of locus of control is very important to increase financial behavior. This study also found that locus of control can contribute to the theory of social construction. Moreover, social construction theory can predict how individuals act to improve their financial behavior
\end{abstract}

Keywords: Locus of control, financial literacy, social construction, accounting student

\section{Introduction}

Financial literacy becomes an issue that has never been solved because it always relates to our daily life. People face difficulties during a major economic crisis because they do not have an emergency fund, meaning they cannot manage their finances well. Thus, when a crisis occurs, they do not have enough savings to support their daily needs. Likewise, when retirees face financial difficulties because they did not adequately prepare their finances, they were still productive. Financial literacy is an issue 
for children to the elderly, issues for various professions, even become a government issue; citizens' financial literacy will encourage a longer growth rate of economic potential (Widdowson \& Hailwood, 2007) and individuals' welfare (Bhushan \& Medury, 2013). Thus, financial literacy must have started as early as possible because it impacts one's future.

The importance of financial literacy on university students attracts governments' attention, academics, and business people. University students are the future leaders and managers; hence, if they do not have strong financial literacy, it may impact their future well-being. It is hoped that students with strong financial literacy can affect their behavior in managing their finances well. Therefore, students must improve financial literacy (Radianto, Wijaya, \& Syahrial, 2020). Usually, when a person decided to become a university student, it can be an early indicator that they can take care of themselves as they have lived apart from their parents. They receive a minimum monthly fund from their parents, so they should manage their finances properly and well. University students are often faced with complicated financial decisions, from paying tuition fees, boarding rent, making a budget, saving their money, taking insurance, and working, so they should have a balanced life at work, college, and social life. These factors increase students' vulnerability to be influenced by external factors, so they are always faced with external and internal factors that control their lives. This condition is often referred to as locus of control. Locus of control is an individual's control over their work and their beliefs in self-success. (Rotter, 1966). Locus of control is divided into two, which are internal that characterizes an individual as someone who believes that they are responsible for their work behavior in an organization. The other factor is the external locus of control, which characterizes as individuals who believe that their work behavior and their job's success are affected by external factors outside of themselves. This is closely related to how students act towards finances and managing their finances. Students who have a high level of external locus of control tend to be affected by other people or the environment in managing their finances. In contrast, those with a high internal locus of control are more likely to solve their financial problems.

Several studies have been conducted on the locus of control. Locus of control is an essential aspect in defining one's behavior but is rarely discussed in the context of financial literacy (Davies \& Lea, 1995; Grable, Joo, \& Park, 2015; Perry \& Morris, 2005; Rotter, 1966). Research by Bapat (2020), Gahara et al. (2020), Siswanti and Halida (2020, and Okicic (2020) found a correlation between locus of control and financial behavior. However, Masdupi and Rasyid (2020) discovered that the relationship between locus of control and financial behavior remains inconsistent. This study attempts to provide an alternative to fill in this research gap. It is interesting to study locus of control in accounting students because these students learn about finances. Thus, there should be a relationship to student's financial behavior and attitudes. Several studies about Locus of control in financial literacy have been conducted (Kesavayuth, Ko, \& Zikos, 2018; Pinger, Schäfer, \& Schumacher, 2018; Prawitz \& Cohart, 2016; Rizkiawati \& Haryono, 2018). This study investigates the role of locus of control in financial literacy from the perspective of the social construction concept. Financial literacy is indicated by financial attitude, financial behavior, and financial self-efficacy (Taft, Hosein, \& Mehrizi, 2013).

This study focuses on university students from the accounting study program. Studying financial literacy in accounting students becomes an important topic as these students will become accountants, auditors, and financial consultants. Accounting students are expected to have financial accounting competencies. They must have a strong foundation in financial literacy; thus, it is hoped that it affects their financial behavior. Accounting students who have the skills and abilities in accounting should manage their finances well and make appropriate financial decisions. This statement will be proven in this research, which examines the effect of locus of towards financial attitude, financial behavior, and financial self-efficacy.

\section{Literature Review}

This study is framed by social construction theory (Berger \& Luckmann, 1991). Individuals who understand the importance of positive social interaction show individuals who have the cognitive 
where individuals' cognitive is an important social capital for economic (Zhang, Lu, \& Zheng, 2020). Humans are viewed as the creators of objective social reality through an externalization process, just as objective reality influences people through the internalization process (Berger \& Luckmann, 1991).

Referring to the social construction theory, when a person interacts with various financial objects and subjects will experience externalization, they will objectify themselves in the financial understanding and knowledge necessary for the present and the future (Rhee \& Choi, 2020). This is strengthened by a legitimacy that arises due to the benefits of understanding finances; for example, a person will not experience financial difficulties because one does not have the financial knowledge and financial attitude. Furthermore, the person will internalize what one should do to gain financial attitude and financial self-efficacy to have a prosperous life. The social construction process will change a person's behavior regarding how a person will manage their finances. A person's social interactions are related to locus of control, which will affect one's finance attitudes (Callois, 2013).

A person who thinks financial management is important will manage their finances. A person who thinks that investment is essential for the future will invest. Similarly, a person who thinks setting aside funds for emergencies is important will save money. Financial attitude is a state of mind, opinion, and evaluation of a person towards their finances, which then applied to their attitude towards finances (Rai, Dua, \& Yadav, 2019). Financial attitudes have an important role in determining a person's success or failure in managing their finances (Çoşkun \& Dalziel, 2020). Coskun and Dalziel (2020) and Herdjiono and Damanik (2016) found that financial attitude affects financial behavior. Thus, the first hypothesis is as follow:

$\mathrm{H}_{1}=$ Financial Attitude affects financial behavior

Individuals' involvement in their financial products reflects how well they manage their finances, be financially responsible, and think about their future (Bandura, 1977). The more individuals believe that they can manage their finance well, the more it can impact their behavior in managing their finances. Studies conducted by Farrell, Fry, and Risse (2016) and Serido, Shim, and Tang (2013) found that financial self-efficacy affects financial behavior. This study shows that individuals who believe in their abilities will make them able to manage their finances well. This finding underlies the second hypothesis, which is:

$\mathrm{H}_{2}=$ Financial Self Efficacy affects Financial behavior

Locus of Control is a person's belief to solve their problem (Ferguson, 1993). This study uses locus of control where individuals who have the locus of control are more likely to be responsible for their actions and behaviors and determine what is right and/or wrong and use it as a guideline for their behaviors. Livingstone and Lunt (1992) found that individuals with a high level of internal locus of control tend to have an excellent financial attitude. Thus, the third hypothesis is:

$\mathrm{H}_{3}=$ Locus of Control affects Financial Attitude

Individuals who believe they can solve their financial problems will improve their abilities in managing their finances and make financial decisions. Pinjisakikool (2017) found that individuals who have a locus of control can relatively make financial decisions. At the same time, Kesavayuth et al. (2018) found that individuals who have a locus of control can manage any financial risks and see the positive side in the financial risks that arise. Thus, the fourth hypothesis is:

$\mathrm{H}_{4}=$ Locus of Control affects financial behavior

Individuals who have an internal locus of control are more likely to believe that they can manage their finances well and are relatively less likely to face financial difficulties (Mien \& Thao, 2015). As a result, the more an individual can overcome one's financial difficulties, the more confident they are in managing their finances. This becomes the basis of the fifth hypothesis, which is:

$\mathrm{H}_{5}=$ Locus of Control affects financial Self-efficacy 


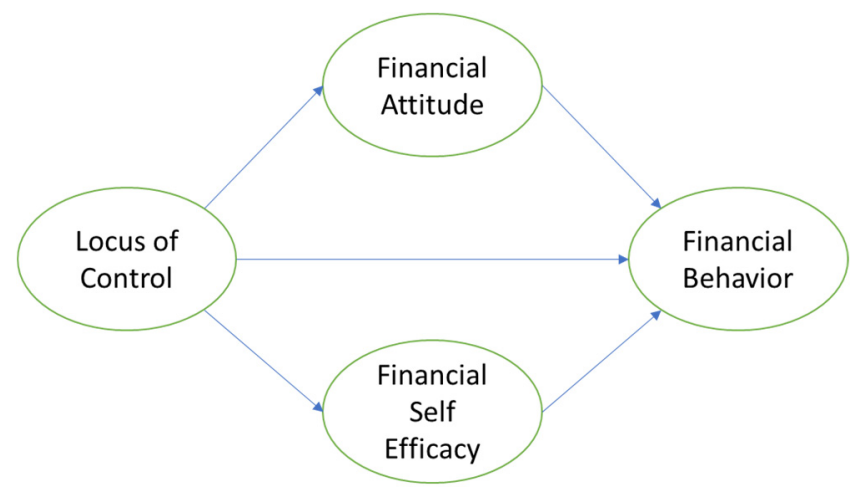

Figure 1: Research Model

\section{Research Method}

This study is based on primary data collected through questionnaires with survey methods. The questionnaires were distributed to accounting students with the help of an enumerator who directly met the prospective respondents. In total, there are 250 questionnaires distributed. One hundred eighty-four questionnaires were collected, which means that the rate of return is 73 percent. However, of the collected questionnaires, 159 questionnaires were completed, or 86 percent.

\subsection{Measurement}

We adopted and developed Financial Attitude and Financial Behavior from Potrich, Vieira, Coronel, \& Bender Filo (2015). Financial attitude is evaluation, opinion, or someone's mental condition towards finance applied to the attitude, and there are eight questions about the attitude towards financial management. A seven-point Likert scale is used for questionnaire responses, with 1 being "unimportant" and 7 being "important". Questions in the questionnaire are regarding attitudes in financial management, including "Controlling expenditure", "Making financial planning", "Saving regularly", "Managing finances for the future", "Having spending plans and following those plans", "Paying off debts", "Always controlling finances following one's budget", and "Investing for the future". Financial behavior is someone's behavior that is related to financial management. Each indicator served on a Likert scale is choice $\mathbf{1}$ for strongly disagree and so on until seven for strongly agree choice. Questions for financial behavior include: "Comparing prices during purchase", "Checking finances when purchasing a relatively expensive thing", "Only buying things that fit into the spending plan", "Paying bills or debts on time", "Noting down all financial transactions in managing income and expenditure", "Having self-control in spending money", "Always comparing when purchasing credit", and "Having enough saving for the next few months".

Financial self-efficacy is someone's trust in managing finance well. We adopt six instruments of financial self-efficacy from Lown (2011). Questions and answers that we adopted from each indicator are: "when I look at the amount of savings I have each month", with the responses measured on a Likert scale, with 1 being "not satisfied" and 7 being "satisfied"; "When I look at the amount of debt I have", with the responses measured on a Likert scale, with 1 being "has an impact on my financial condition" and 7 being "has no impact on my financial condition"; "When I see my ability in fulfilling my needs", with the responses measured on a Likert scale, with 1 being "unable to fulfill my needs" and 7 being "able to fulfill my needs"; "When something unwanted/an emergency happens", with the responses measured on a Likert scale, with 1 being "unable to fulfill my needs" and 7 being "able to fulfill my needs", and "When I see myself in managing my finances", with the responses measured on a Likert 
scale, with 1 being "quite able to manage my finances" and 7 being "able to manage my finances".

Locus of control is how confident an employee is in facing various difficulties and challenges at work. We adopted the locus of control from Ferguson (1993). Several instruments include "a person's ability to locate and solve a problem", "a person's ability in facing pressure", "a person's ability in changing their life", "a person's ability in doing everything", "a person's ability in controlling their future", and "a person's ability in managing themselves". Each indicator presented in Table 1 is stated according to the Likert scale, ranging from 1 for Strongly Disagree to 7 for Strongly Agree. The analytical tool in this study is based on multiple regression analysis.

\section{Result and Discussion}

As mentioned previously, 159 data can be processed and chosen as the final sample group of this research. The demographic distribution of the respondents is shown in Table 2 below.

Table 2. Demographic Distribution of Research Respondents ( $n=159)$

\begin{tabular}{lcc}
\hline Demographics & Frequency & Percentage (\%) \\
\hline Gender & & \\
$\bullet$ Male & 38 & 24 \\
$\bullet$ Female & 121 & 76 \\
\hline Age & & \\
$\bullet \leq 20$ & 134 & 84 \\
$\bullet>20$ & 25 & 16 \\
\hline Monthly spending (million rupiah) & & \\
$\bullet$ below 3 & 102 & 64 \\
$-3-5$ & 48 & 30 \\
$\bullet$ above 5 & 9 & 6 \\
\hline Level of Studies & & \\
- Junior Students & 103 & 65 \\
- Senior Students & 56 & 35 \\
\hline
\end{tabular}

As shown in Table 2, 24 percent of the respondents are male, while 76 percent are female. Respondents age 20 years old or younger are 134 people (84 percent) and those who are 20 years and older are 25 ( 16 percent). Most of the respondents' monthly spending is 3 million and below, which areio2 people (64 percent). There are 56 senior students ( 35 percent) and 103 junior students ( 65 percent). The data shown in Table 2 shows that most respondents are characterized as having a monthly spending of 3 million rupiah and are junior students in the accounting study program.

\subsection{Descriptive Analysis of the Variable Characteristics}

The descriptive analysis of each research variable is presented in Table 3. On average, the respondent's answers on locus of control, financial attitude, financial behavior, and financial-self efficacy lie around 5 on a scale of 1 to 7 . In comparison, financial attitude is close to 7 . This means that, on average, the respondents agree with the indicators presented in the questions.

Table 3. Statistic Descriptions of the Research Variables ( $\mathrm{N}=159)$

\begin{tabular}{clcc}
\hline No & Variable & Mean & Standard Deviation \\
\hline 1 & Locus of Control & 5.1879 & .69901 \\
2 & Financial Attitude & 6.4118 & .61334 \\
3 & Financial Behavior & 5.6622 & .80307 \\
4 & Financial Self-efficacy & 4.9979 & .94480 \\
\hline
\end{tabular}




\subsection{Evaluation of the Measurement Models}

The testing was conducted by PLS-SEM, which includes measurement model and structural model testing. The assessment of the measurement model includes convergent validity, discriminant validity, and construct reliability testing. The loading value of each item tests convergent validity. The acceptance value must show that the loading value is greater than 0.7. Thus, the researchers removed some items because the loading value is lower than 0.7 (Hair et al., 2017). Thereafter, the table below shows the result of convergent validity.

Table 4. Loading, Average Variance Extracted, and Composite Reliability of Construct

\begin{tabular}{|c|c|c|c|c|}
\hline Construct & Item Label & Loading & Average Variance Extracted & Composite Reliability \\
\hline \multirow[t]{6}{*}{ Financial Attitude } & & & 0.586 & 0.876 \\
\hline & FA1 & 0.732 & & \\
\hline & FA2 & 0.787 & & \\
\hline & $\mathrm{FA}_{4}$ & 0.718 & & \\
\hline & $\mathrm{FA}_{5}$ & 0.798 & & \\
\hline & $\mathrm{FA}_{7}$ & 0.787 & & \\
\hline \multirow{4}{*}{ Financial Behavior } & & & 0.585 & 0.809 \\
\hline & FB2 & 0.768 & & \\
\hline & $\mathrm{FB}_{3}$ & 0.784 & & \\
\hline & $\mathrm{FB}_{7}$ & 0.742 & & \\
\hline \multirow[t]{4}{*}{ Financial Self Efficacy } & & & 0.709 & 0.88 \\
\hline & $\mathrm{FS}_{4}$ & 0.842 & & \\
\hline & $\mathrm{FS}_{5}$ & 0.799 & & \\
\hline & FS6 & 0.883 & & \\
\hline \multirow[t]{4}{*}{ Locus of Control } & & & 0.599 & 0.817 \\
\hline & L1 & 0.791 & & \\
\hline & $\mathrm{L}_{3}$ & 0.797 & & \\
\hline & $\mathrm{L}_{4}$ & 0.731 & & \\
\hline
\end{tabular}

Table 4 shows that the outer loading value is $>0.7$, thus is fulfills the convergent validity requirement. Likewise, the value of Average Variance Extracted (AVE) on each variable shows a value of $>0.5$. So, these two conditions have fulfilled the convergent validity requirement. Next, we conducted $a$ Discriminant validity test, which explains how far the existing construct was different than other constructs within the model. The method used is the Fornell-Larcker criterion (Hair et al., 2017; Fornell \& Larcker, 1981). Namely, by comparing the square root of AVE with the absolute value of the variable correlation value. AVE's square root must be higher than the variable correlation, as seen in Table 5 where the highest correlation value is $\mathbf{0 . 4 2 2}$, which is lower than 0.765 . The result of the Fornell-Larcker criterion is presented in Table 5 .

Table 5: Fornell-Larcker Criterion

\begin{tabular}{lcccc}
\hline & Financial Attitude & Financial Behavior & Financial Self-Efficacy & Locus of Control \\
\hline Financial Attitude & $\mathbf{0 . 7 6 5}$ & & & \\
Financial Behavior & 0.365 & $\mathbf{0 . 7 6 5}$ & & \\
Financial Self-Efficacy & 0.248 & 0.38 & $\mathbf{0 . 8 4 2}$ & \\
Locus of Control & 0.188 & 0.442 & $\mathbf{0 . 2 9 7}$ & $\mathbf{0 . 7 7 4}$ \\
\hline
\end{tabular}

It can be seen from Table 5 that the square root value of AVE is higher than the variable correlation value, which is shown in the relevant row or column. Thus, it can be concluded that each construct consistently fulfills the discriminant validity requirement by using two testing methods. Furthermore, 
we conduct a composite reliability test. The result, shown in Table 4, shows that the lowest composite reliability value is 0.809 on the Financial Behavior variable, and the highest value is 0.876 on the Financial Attitude variable. The value of composite reliability ranges from 0.70 to 0.90 , which is satisfactory (Nunally \& Bernstein, 1994).

Next, we conduct a hypothesis testing the path coefficient and p-value from each hypothesis. As shown in Table 6 below.

Table 6: Results of Hypothesis Testing

\begin{tabular}{llccc}
\hline & Hypothesis & Path coefficient & p-value & Supported \\
\hline $\mathrm{H}_{1}$ & Financial Attitude $\rightarrow$ Financial Behavior & 2.566 & 0.005 & Yes \\
$\mathrm{H}_{2}$ & Financial Self-Efficacy $\rightarrow$ Financial Behavior & 2.669 & 0.004 & Yes \\
$\mathrm{H}_{3}$ & Locus of Control $\rightarrow$ Financial Attitude & 2.525 & 0.006 & Yes \\
$\mathrm{H}_{4}$ & Locus of Control $\rightarrow$ Financial Behavior & 3.354 & 0.000 & Yes \\
$\mathrm{H}_{5}$ & Locus of Control $\rightarrow$ Financial Self Efficacy & 3.969 & 0.000 & Yes \\
\hline
\end{tabular}

According to the coefficient and p-value from each hypothesis, all hypotheses are supported. Also, the value of $\mathrm{R}^{2}$ on construct financial attitude is 0,035 , which means that the locus of control on financial attitude is $3.5 \%$. The value of R2 in financial behavior is 0.320 , which means that locus of control, financial attitude, and financial self-efficacy affect financial behavior by $32 \%$. The value of $\mathrm{R}^{2}$ on construct financial self-efficacy is 0.088 , meaning that locus of control affects financial self-efficacy by $8.8 \%$

\section{Discussion}

The context of social construction stated that the knowledge possessed by an individual is a result of interaction with external parties that will be internalized within oneself, making the person performs social actions. A person who has correct financial behaviors will certainly have a prior financial understanding (Huston, 2010; Lind et al., 2020). Thus, internalization is shown by having the right financial attitude, which will affect their rational actions in managing finances. Therefore, this study found that Financial Attitude positively affects financial behavior. The objectification process carried out by individuals based on the context of social interaction will map out what constitutes the right finance-related attitudes, such as savings is important to have an emergency fund, and investment is very important for one's future. This will be internalized within a person and the person will construct a logic about what one should do to prevent them from having financial management issues. This study found that the internalization process and a person's construction based on the result of objectification can affect a person's social behavior in managing their finances. The legitimacy of the importance of financial attitude acquired from internalization is shown to affect a person's ability to make financial decisions.

Individuals who have the right attitude to finance affect how they manage their finances and make financial decisions. Individuals who address the importance of financial management will be careful and measure their spending, saving their funding, and investing. Financial attitude is seen from how individuals control their spending carefully. For example, when they are going to shop, they compare prices and check their financial condition. In social construction theory, this is a phase of how a person internalized the importance of managing finances. The better their financial attitude is, the better their financial behavior will be. This means that the right attitude in managing their finances will improve their ability to manage their money. This finding supports Coskun and Dalziel (2020) and Çoşkun and Dalziel (2020), who found that financial attitude affects financial behavior.

Financial self-efficacy positively affects financial behavior. Financial self-efficacy in finance is one's belief that people can manage their finances. It turns out that individuals who have financial selfefficacy have a positive effect on one's financial management. The higher individuals' confidence in 
managing their finances, the more chances they have in making correct financial decisions. Individuals in an emergency financial situation will have the confidence to fulfill their financial needs so that they will be wiser in spending their money and prioritizing their needs over their wants.

When Individuals who have a high level of self-efficacy have debt, the debt will not affect their cash-flow because they can manage their finances well. Individuals who have financial self-efficacy will carefully spend their money and set aside parts of their income for a precautionary fund. Some decided to invest their money in the right investment product. It indicates that when an individual who is confident in one's ability to manage their money will make an effective and efficient financial decision. It can happen when the individual can internalize social construction by identifying what one should do to impact one's financial behavior. This study supports past researches conducted by Serido et al. (2013) and Farrell et al. (2016), who found that financial efficacy affects financial behavior. Furthermore, this finding also supports Lown's (2011) research that found self-efficacy will affect people's behavior; in this case, their financial attitude.

Locus of control affects financial attitude, financial behavior, and financial self-efficacy. Rotter (1966) stated that an internal locus of control is how an individual believes that one's abilities are in control of events in their life. The higher their internal locus of control towards financial is, the more they show the right financial attitude. When a person can make financial decisions and are responsible for managing their finances, they are more likely to portray good financial attitudes. Individuals' ability to control their expenses is important because these individuals can control themselves well. Individuals who can control the environment will try to have financial plans to control their finances. It will affect individuals to be disciplined because they think these are the right actions to manage finances. Because these individuals can manage events that arise, thus they will always try to manage the budgets that they have made. This finding supports researches by Ferguson (1993) and Livingstone and Lunt (1992).

A person's financial behavior is affected by the internal locus of control. The better individuals are in overcoming financial problems, the better they are in managing their finances well. The higher individuals' ability to overcome financial challenges and obstacles, the better they are at making appropriate financial decisions. Internal locus of control in financial management is an activity to act in self-control. For example, when an individual can control oneself well, the person can create a wellthought budget planning, including ways to manage savings, an investment, and credit payments. This study supports researches by Pinger et al. (2018) and Cobb-Clark and Schurer (2012). They found that locus of control affects an individual's behavior in choosing investment, especially stocks, and affects how one manages savings. Likewise, Pinjisakikool (2017) found that locus of control affects financial behavior.

Locus of control affects financial self-efficacy. The more individuals feel that they could manage their finances, the more they believe that they manage their finances. Individuals who believe that they can overcome financial problems are more likely to manage their finances well. This study support research by Mien and Thao (2015), who found that a low internal locus of control increases the potential to face financial problem. On the other hand, individuals who have a higher internal locus of control are more likely to believe that they can manage their finances.

This study contributes to the social construction theory on how people construct financial behavior. It proves that the process of changing financial behavior can be predicted by social construction theory through the role of locus of control in affecting financial literacy (financial attitude, financial self-efficacy, and financial behavior). An individual can change other's mindsets about the importance of financial management through the process of interaction-externalization. A high external locus of control will easily be influenced by external, while one's skills and knowledge can influence a high internal locus of control. (Kavish, Helton, Vaughn, \& Boutwell, 2020). This process occurs from interactions with objects related to finances. Internalization within oneself triggers the person to identify what they need to do to avoid financial problems through managing their money. It means that a person will change their rational actions in managing finances and construct new actions to make deliberate financial actions that deem appropriate. 
Individuals' interactions will significantly impact individuals' role and social involvement (Rhee \& Choi, 2020). Positive social interaction will affect an individual's' financial understanding so that the individuals will have the appropriate financial behavior. Individuals who understand the importance of positive social interaction show that the individuals have the cognitive abilities where their cognitive is an important social capital that is important for the economic efficiencies than the structural social capital (Callois, 2013). Social capital owned by individuals is crucial because it is an important aspect that serves as the basis for a person to objectify and legitimize social objects or subjects.

This study implies the importance of the social interaction process from each individual to influence individuals' social actions from those who did not understand the importance of financial management literacy to those who have the right attitude about the importance of finances. It impacts their ability to manage and make financial decisions. A person who has experienced externalization and could identify important aspects of finances will have the right attitude towards finances. After a person has the right financial attitude, the person will go through an internalization process. The person will decide or identify actions that they need to take that relate to one's financial condition. Next, the person will construct individual actions based on one's understanding of what they should do, for example, to have savings for emergency funds, to invest in preparing their future, or to have insurance to protect oneself from accidents. The social construction process will take place continuously (Sica, 2016).

\section{Conclusion}

This study examines the effect of financial attitude, financial self-efficacy, and locus of control towards financial behavior. There are 159 questionnaires collected from the respondents, who include students from the accounting program. The study found that financial attitude, financial self-efficacy, and locus of control affect financial behavior. The more the students have the right attitude towards finances, have the belief to manage their finances, and overcome financial problems, the better their financial behavior is. Furthermore, this study also found that locus of control is an important aspect that affects financial literacy.

This study contributes to an understanding of where the locus of control becomes an important determinant of accounting students' financial activities. Internal locus of control holds a vital role in affecting accounting student's financial literacy. It may happen because accounting students have received information about finances since their first year of study; thus, they have been exposed to financial matters. It is caused by better financial knowledge and skills, which can influence how well they act towards their finances, manage their finances well, and believe that they can manage finances. Social construction theory can explain the process of how a person can obtain the right financial behaviors.

This study finds that locus of control is an important determinant of the financial behavior of accounting students. Internal locus of control has an essential role in affecting the accounting students' financial literacy. This is because accounting students have received financial knowledge since their first year, so they have been exposed to financial knowledge. This results in relatively good financial knowledge and skills that result in their having the right behavior towards money, good financial management, and their belief that they can manage their finances. The social construction theory managed to explain how a person goes through to have the right financial behavior. In the context of social construction, financial behavior is a result of an individual's construction after the individual went through an internalization process caused by the externalization facts from the social environment. Furthermore, the researchers found that locus of control is an important variable in social construction to influence the result of financial literacy. In the context of social construction, financial knowledge and skills are an important social capital and affect an individual's internalization process, hence results in a change in an individual's behavior.

This study opens new opportunities to conduct further studies by developing whether there are differences in the internal and external locus of control in influencing financial literacy. The aspect of 
gender can also be added to future research because of social-cultural construction in society. Several studies still show inconsistent results rearing the effect of gender on financial literacy.

\section{Acknowledgment}

The author wants to express thanks to the Directorate of Research and Community Service at the Ministry of Research and Technology, the Republic of Indonesia for providing the funding of this research.

\section{References}

Bandura, A. (1977). Self-efficacy: toward a unifying theory of behavioral change. Psychological review, 84(2), 191. doi:10.1037/0033-295X.84.2.191

Berger, P. L., \& Luckmann, T. (1991). The social construction of reality: A treatise in the sociology of knowledge: Penguin Uk.

Bhushan, P., \& Medury, Y. (2013). Financial literacy and its determinants. International Journal of Engineering, Business and Enterprise Applications, 4(2), 155-160.

Callois, J. M. (2013). Social interaction and economic organization: Toward an integrative microeconomic model. . Economics Letters, 121(1), 98-100. doi:10.1016/j.econlet.2013.07.013

Cobb-Clark, D. A., \& Schurer, S. (2012). The stability of big-five personality traits. Economics Letters, 115(1), 11-15. doi:10.1016/j.econlet.2011.11.015

Coskun, A., \& Dalziel, N. (2020). Mediation effect of financial attitude on financial knowledge and financial behavior: The case of university students. . International Journal of Research in Business and Social Science, 9(2), 1-8. doi:10.20525/ijrbs.v9i2.647

Çoşkun, A., \& Dalziel, N. (2020). Mediation effect of financial attitude on financial knowledge and financial behavior. International Journal of Research in Business and Social Science 9(2), o1-08. doi:10.20525/ijrbs.v9i2.647

Davies, E., \& Lea, S. E. (1995). Student attitudes to student debt. Journal of Economic Psychology, 16(4), 663-679. doi:10.1016/0167-4870(96)80014-6

Farrell, L., Fry, T. R. L., \& Risse, L. (2016). The significance of financial self-efficacy in explaining women's personal finance behaviour. Journal of Economic Psychology, 54, 85-99. doi:10.1016/j.joep.2015.07.001

Ferguson, E. (1993). Rotter's locus of control scale: A ten-item two-factor model. Psychological Reports, 73, 12671278. doi:10.2466/pro.1993.73.3f.1267

Grable, J. E., Joo, S. H., \& Park, J. (2015). Exploring the Antecedents of Financial Behavior for Asians and NonHispanic Whites: The Role of Financial Capability and Locus of Control. Journal of Personal Finance, 14(1), 2837 .

Herdjiono, I., \& Damanik, L. A. (2016). Pengaruh Financial Atti Tude, Financial Knowledge, Parental Income Terhadap Financial Management Behavior. Jurnal Manajemen Teori dan Terapan, 9(3), 226-241.

Huston, S. (2010). Measuring Financial Literacy. Journal of Consumer Affairs, 44, 296-316. doi:10.1111/j.17456606.2010.01170.x

Kavish, N., Helton, J., Vaughn, M. G., \& Boutwell, B. B. (2020). The association of externalizing and internalizing problems with indicators of intelligence in a sample of at-risk children. Intelligence, 8o(February), 101448. doi:10.1016/j.intell.2020.101448

Kesavayuth, D., Ko, K. M., \& Zikos, V. (2018). Locus of control and financial risk attitudes. . Economic Modelling, 72, 122-131. doi:10.1016/j.econmod.2018.01.010

Lind, T., Ahmed, A., Skagerlund, K., Strömbäck, C., Västfjäll, D., \& Tinghög, G. (2020). Competence, Confidence, and Gender: The Role of Objective and Subjective Financial Knowledge in Household Finance. Journal of Family and Economic Issues, 1-13. doi:10.1007/s10834-020-09678-9

Livingstone, S. M., \& Lunt, P. K. (1992). Predicting personal debt and debt repayment: Psychological, social and economic determinants. . ournal of economic psychology, 13(1), 111-134.

Mien, N. T. N., \& Thao, T. P. (2015, 10-12 July). Factors Affecting Personal Financial Management Behaviors: Evidence from Vietnam. Paper presented at the the Second Asia-Pacific Conference on Global Business, Economics, Finance and Social Sciences (AP15Vietnam Conference), Vietnam.

Perry, V. G., \& Morris, M. D. (2005). Who is in control? The role of self-perception, knowledge, and income in explaining consumer financial behavior. Journal of Consumer Affairs, 39, 299-313. doi:10.1111/ j.1745$6606.2005 .00016 . x$ 
Pinger, P., Schäfer, S., \& Schumacher, H. (2018). Locus of control and consistent investment choices. . Journal of Behavioral and Experimental Economics,, . 75, 66-75. doi:10.1016/j.socec.2018.05.004

Pinjisakikool, T. (2017). The effect of personality traits on households' financial literacy. Citizenship, Social and Economics Education, 16(1), 39-51. doi:10.1177/2047173417690005

Prawitz, A. D., \& Cohart, J. (2016). Financial Management Competency, Financial Resources, Locus of Control, and Financial Wellness. Journal of Financial Counseling and Planning, 27(2), 142-157. doi:10.1891/1052-3073.27.2.142

Radianto, W. E. D., Wijaya, O. Y. A., \& Syahrial, R. (2020). Young Entrepreneur, Parental Socioeconomic Status, and Financial Literacy: Does Supply Chain Mediate Entrepreneurship Education? International Journal of Supply Chain Management, 9(4), 317-323.

Rai, K., Dua, S., \& Yadav, M. (2019). Association of Financial Attitude, Financial Behaviour and Financial Knowledge Towards Financial Literacy: A Structural Equation Modeling Approach. FIIB Business Review, 8(1), 51-6o. doi:10.1177/2319714519826651

Rhee, C. E., \& Choi, J. (2020). Effects of personalization and social role in voice shopping: An experimental study on product recommendation by a conversational voice agent. . Computers in Human Behavior, 109(March), 106359. doi:doi.org/10.1016/j.chb.2020.106359

Rizkiawati, N. U. R., \& Haryono, N. A. D. I. A. (2018). Pengaruh Demografi, Financial Knowledge, Financial Attitude, Locus Of Control Dan Financial Self-Efficacy Terhadap Financial Management Behavior Masyarakat Surabaya. (Jim), 6(3). Jurnal Ilmu Manajemen, 6(3), 93-107.

Rotter, J. B. (1966). Generalized expectancies for internal versus external control of reinforcement. . Psychological monographs: General and applied, 8o(1), 1-28.

Serido, J., Shim, S., \& Tang, C. (2013). A developmental model of financial capability: A framework for promoting a successful transition to adulthood. International Journal of Behavioral Development, 37(4), 287-297. doi:10.1177/0165025413479476

Sica, A. (2016). Social Construction as Fantasy: Reconsidering Peter Berger and Thomas Luckmann's The Social Construction of Reality after 5o Years. Cultural Sociology, 10(1), 37-52. doi:10.1177/1749975515614869

Taft, M. K., Hosein, Z. Z., \& Mehrizi, S. M. T. (2013). The Relation between Financial Literacy, Financial Wellbeing and Financial Concerns. International Journal of Business and Management, 8(11). doi:10.5539/ijbm.v8n11p63

Widdowson, D., \& Hailwood, K. (2007). Financial literacy and its role in promoting a sound financial system. Reserve Bank of New Zealand Bulletin, 70(2), 37-47.

Zhang, Y., Lu, B., \& Zheng, H. (2020). Can buzzing bring business? Social interactions, network centrality and sales performance: An empirical study on business-to-business communities. Journal of Business Research, 112, 170189. 